\title{
Pyridoxine Deficiency-Associated Peroxidative Changes in Rats and the Salubrious Effects of Structurally Related Triterpenes
}

\author{
Lakshminarasimhan VIDYA, Mahimainathan LENIN, and \\ Palaninathan VARALAKSHMI* \\ Department of Medical Biochemistry, Dr. A.L.M. Post Graduate Institute of Basic \\ Medical Sciences, University of Madras, Taramani, Chennai 600 113, India
}

(Received October 16, 1999)

\begin{abstract}
Summary Pyridoxine-deficient rats showed increased lipid peroxidation in the kidney when compared with control rats, and the lipid peroxidation was enhanced in the presence of inducers such as ascorbate and hydrogen peroxide. Pyridoxine-deficient kidney showed decreased levels of enzymic antioxidants such as glutathione peroxidase, superoxide dismutase, catalase, glutathione reductase, and glucose-6-phosphate dehydrogenase and non-enzymic antioxidants including ascorbate, glutathione and vitamin E. Treatment with the triterpenes - betulin and lupeolrestored the levels to normal, the latter being more effective in bringing about the changes.
\end{abstract}

Key Words: lipid peroxidation, triterpenes, antioxidants, betulin, lupeol

Vitamin $\mathrm{B}_{6}$ plays a central role in amino acid metabolism. Apart from that, oxalate metabolism is the major pathway in which pyridoxine plays a pivotal role. It acts as a cofactor in the transamination of glyoxylate, the precursor of oxalate, to glycine. A deficiency in vitamin $B_{6}$ manifests itself as hyperoxaluria due to increased oxalate synthesis in the liver by glycolic acid oxidase [1]. Crystal deposition in the kidney has been reported to induce lipid peroxidation [2]. Triterpenes such as oleanolic and ursolic acids have been shown to protect against peroxidative damage [3]. Hence, evaluation of the related triterpenes-betulin and lupeol - on the peroxidative status in hyperoxaluric rats was undertaken in the present study.

* To whom correspondence should be addressed. 


\section{MATERIALS AND METHODS}

Betulin was obtained from Sigma Chemicals, St. Louis, MO, USA; and lupeol was isolated in our laboratory from the stem bark of Crataeva nurvala [4].

Male albino rats of the Wistar strain (150-180 g) were used. The animals were housed under standard conditions of temperature $\left(23 \pm 1^{\circ} \mathrm{C}\right)$, relative humidity (55 $\pm 10 \%), 12$-h light/12-h dark cycle. They were divided into six groups of six rats each. Group I served as controls. Hyperoxaluria was induced in Group II rats by feeding a diet deficient in pyridoxine and containing 3\% glycolic acid [5]. Groups III and IV served as drug controls and were each given $35 \mathrm{mg} / \mathrm{kg} \mathrm{b.wt./d/rat,} \mathrm{p.o.,}$ of betulin and lupeol, respectively. Groups V and VI were maintained on the pyridoxine-deficient diet and simultaneously treated with betulin and lupeol (35 $\mathrm{mg} / \mathrm{kg}$ b.wt./d/rat, p.o.), respectively. The control rats were maintained on pyridoxine-supplemented feed ( $4 \mathrm{mg} / \mathrm{kg}$ feed), described by Chow et al. [5]. The animal experiments were conducted according to the guidelines for the care and use of laboratory animals in our university.

At the end of 21 days, the rats were decapitated, and their kidneys removed and homogenized in Tris- $\mathrm{HCl}$ buffer $(0.1 \mathrm{M}, \mathrm{pH} 7.4)$. A $10 \%$ homogenate was used to estimate lipid peroxidation levels and the antioxidant status [6]. The enzymic antioxidants including glutathione peroxidase (GPx), catalase, superoxide dismutase (SOD), glucose-6-phosphate dehydrogenase (G6PD), glutathione reductase (GR), and glutathione- $S$-transferase (GST) and non-enzymic antioxidant such as

Table 1. Effect of PDD and triterpenes on oxalate levels and lipid peroxidation.

\begin{tabular}{|c|c|c|c|c|c|c|}
\hline Constituent & $\begin{array}{c}\text { Group I } \\
\mathrm{C}\end{array}$ & $\begin{array}{l}\text { Group II } \\
\text { PDD }\end{array}$ & $\begin{array}{c}\text { Group III } \\
\mathrm{C}+\mathrm{B}\end{array}$ & $\begin{array}{c}\text { Group IV } \\
\mathrm{C}+\mathrm{L}\end{array}$ & $\begin{array}{l}\text { Group V } \\
\text { PDD + B }\end{array}$ & $\begin{array}{c}\text { Group VI } \\
\text { PDD }+\mathrm{L}\end{array}$ \\
\hline $\begin{array}{l}\text { Oxalate } \\
\text { (urine) }\end{array}$ & $2.83 \pm 0.12$ & $\begin{array}{c}8.47 \pm 0.65 \\
a^{*}\end{array}$ & $\begin{array}{r}2.64 \pm 0.11 \\
b^{*}\end{array}$ & $\begin{array}{r}2.74 \pm 0.10 \\
b^{*}\end{array}$ & $\begin{array}{r}3.64 \pm 0.28 \\
a^{*} b^{*} c^{*} d^{*}\end{array}$ & $\begin{array}{c}3.52 \pm 0.21 \\
a^{\#} b^{*} c^{*} d \#\end{array}$ \\
\hline $\begin{array}{l}\text { Oxalate } \\
\text { (kidney) }\end{array}$ & $4.89 \pm 0.30$ & $\begin{array}{r}10.13 \pm 0.94 \\
a^{*}\end{array}$ & $\begin{array}{r}5.11 \pm 0.26 \\
b^{*}\end{array}$ & $\begin{array}{r}5.31 \pm 0.31 \\
b^{*}\end{array}$ & $\begin{array}{l}6.78 \pm 0.38 \\
a^{*} b^{*} c^{*} d^{*}\end{array}$ & $\begin{array}{c}6.4 \pm 0.51 \\
a^{*} b^{*} c^{\#} d^{\#}\end{array}$ \\
\hline Basal & $4.10 \pm 0.26$ & $\begin{array}{r}5.63 \pm 0.38 \\
a^{*}\end{array}$ & $\begin{array}{r}3.98 \pm 0.28 \\
b^{*}\end{array}$ & $\begin{array}{r}4.20 \pm 0.27 \\
b^{*}\end{array}$ & $\begin{array}{r}3.93 \pm 0.21 \\
b^{*}\end{array}$ & $\begin{array}{r}4.39 \pm 0.30 \\
b^{*}\end{array}$ \\
\hline $\begin{array}{l}\text { I } \mathrm{mm} \\
\text { ascorbate }\end{array}$ & $6.43 \pm 0.41$ & $\begin{array}{r}7.86 \pm 0.52 \\
a^{*}\end{array}$ & $\begin{array}{r}6.16 \pm 0.38 \\
b^{*}\end{array}$ & $\begin{array}{r}6.34 \pm 0.44 \\
b^{*}\end{array}$ & $\begin{array}{l}5.26 \pm 0.38 \\
\mathrm{a}^{\#} \mathrm{~b}^{*} \mathrm{c}^{\#} \mathrm{~d}^{\#}\end{array}$ & $\begin{array}{c}6.33 \pm 0.35 \\
b^{*} \mathrm{e}^{\#}\end{array}$ \\
\hline $10 \mathrm{mM} \mathrm{FeSO}_{4}$ & $7.79 \pm 0.55$ & $8.18 \pm 0.48$ & $7.50 \pm 0.56$ & $7.80 \pm 0.49$ & $\begin{array}{l}6.30 \pm 0.36 \\
a^{*} b^{*} c^{*} d^{*}\end{array}$ & $\begin{array}{r}7.80 \pm 0.51 \\
\mathrm{e}^{*}\end{array}$ \\
\hline $10 \mathrm{mM} \mathrm{H}_{2} \mathrm{O}_{2}$ & $4.55 \pm 0.31$ & $\begin{array}{r}6.10 \pm 0.52 \\
\mathrm{a}^{*}\end{array}$ & $\begin{array}{r}4.21 \pm 0.36 \\
b^{*}\end{array}$ & $\begin{array}{r}4.44 \pm 0.28 \\
b^{*}\end{array}$ & $\begin{array}{l}5.07 \pm 0.35 \\
\mathrm{a}^{@} \mathrm{~b}^{*} \mathrm{c}^{\#} \mathrm{~d}^{@}\end{array}$ & $\begin{array}{c}6.02 \pm 0.45 \\
\mathrm{a}^{*} \mathrm{c}^{*} \mathrm{~d}^{*} \mathrm{e}^{*}\end{array}$ \\
\hline
\end{tabular}

Values represent mean \pm SD for six rats. Treatment of groups: Group I, control (C); Group II, pyridoxine-deficient (PDD) rats; Group III, control+betulin (B); Group IV, control+ lupeol (L); Group V, pyridoxine-deficient rats + betulin; Group VI, pyridoxine-deficient rats + lupeol. Units: Lipid peroxidation in kidney, nmol of MDA formed $/ \mathrm{min} / \mathrm{mg}$ protein; oxalate, $\mathrm{mg} / 24 \mathrm{~h}$ urine and $\mathrm{mg} / \mathrm{g}$ wet tissue. Comparisons are made: a, with Group I; b, with Group II; c, with Group III; d, with Group IV; e, with Group V. Symbols represent statistical significance: ${ }^{@} p<0.05 ;{ }^{\#} p<0.01 ;{ }^{*} p<0.001$. 
glutathione (GSH) were estimated by standard protocols followed in our laboratory [6]. Ascorbic acid and vitamin E were quantified by the methods adopted by Omaye et al. [7] and Quaife and Dju [8], respectively.

\section{RESULTS}

Oxalate levels in the urine and kidney of the pyridoxine-deficient rats indicated hyperoxaluria and crystal deposition (Table 1). There was a marked reduction in the oxalate levels on treatment with the triterpenes. The level of malondialdehyde (MDA) released, which indicates the extent of lipid peroxidation in the kidney of the experimental animals, is also shown in Table 1. Basal, ascorbate-, and hydrogen peroxide-induced lipid peroxidation was found to be increased in the pyridoxine-deficient animals when compared with their control levels. Restoration of normal levels was seen only in the lupeol-treated animals. The antioxidant status of the kidney was decreased as evidenced from the decreased activities of the enzymic antioxidants GPx, catalase, SOD, GR, and G6PD and of the non-enzymic antioxidants GSH, ascorbate, and vitamin E. GST levels were found to be unaffected (Table 2). Administration of lupeol and betulin brought about a

Table 2. Effect of betulin and lupeol on antioxidant status in kidney of PDD fed rats.

\begin{tabular}{|c|c|c|c|c|c|c|}
\hline $\begin{array}{c}\text { Constituent } \\
\text { (units } / \mathrm{min} / \mathrm{mg} \\
\text { protein) }\end{array}$ & $\begin{array}{c}\text { Group I } \\
\text { C }\end{array}$ & $\begin{array}{l}\text { Group II } \\
\text { PDD }\end{array}$ & $\begin{array}{c}\text { Group III } \\
\mathrm{C}+\mathrm{B}\end{array}$ & $\begin{array}{c}\text { Group IV } \\
\mathrm{C}+\mathrm{L}\end{array}$ & $\begin{array}{l}\text { Group V } \\
\text { PDD + B }\end{array}$ & $\begin{array}{l}\text { Group VI } \\
\text { PDD }+\mathrm{L}\end{array}$ \\
\hline \multirow[t]{2}{*}{ GPx } & $17.17 \pm 1.23$ & $12.45 \pm 1.10$ & $16.97 \pm 1.41$ & $16.48 \pm 1.52$ & $16.70 \pm 1.08$ & $15.88 \pm 1.14$ \\
\hline & & $\mathrm{a}^{*}$ & $b^{*}$ & $b^{*}$ & $b^{*}$ & $b^{*}$ \\
\hline \multirow[t]{2}{*}{ Catalase } & $242 \pm 20$ & $107 \pm 8$ & $236 \pm 19$ & $240 \pm 20$ & $222 \pm 20$ & $231 \pm 19$ \\
\hline & & $\mathrm{a}^{*}$ & $b^{*}$ & $b^{*}$ & $b^{*}$ & $b^{*}$ \\
\hline \multirow[t]{2}{*}{ SOD } & $4.20 \pm 0.31$ & $3.24 \pm 0.25$ & $4.08 \pm 0.39$ & $4.44 \pm 0.37$ & $4.02 \pm 0.29$ & $4.14 \pm 0.32$ \\
\hline & & $\mathrm{a}^{*}$ & $\mathrm{~b}^{*}$ & $b^{*}$ & $b^{*}$ & $b^{*}$ \\
\hline \multirow[t]{2}{*}{ GR } & $2.34 \pm 0.14$ & $1.93 \pm 0.16$ & $2.11 \pm 0.18$ & $2.38 \pm 0.15$ & $2.52 \pm 0.18$ & $2.48 \pm 0.17$ \\
\hline & & $\mathrm{a}^{\#}$ & $\mathrm{a}^{@}$ & $\mathrm{~b} * \mathrm{c}^{@}$ & $\mathrm{~b}^{*} \mathrm{c}^{\#}$ & $\mathrm{~b}^{*} \mathrm{c}^{\#}$ \\
\hline GST & $28.50 \pm 1.84$ & $25.25 \pm 2.46$ & $26.75 \pm 2.12$ & $27.21 \pm 2.31$ & $25.80 \pm 2.11$ & $27.25 \pm 1.68$ \\
\hline \multirow[t]{2}{*}{ G6PD } & $2.36 \pm 0.22$ & $1.96 \pm 0.07$ & $2.21 \pm 0.15$ & $2.16 \pm 0.17$ & $2.14 \pm 0.18$ & $2.13 \pm 0.15$ \\
\hline & & $\mathrm{a}^{\#}$ & & & & \\
\hline \multicolumn{7}{|c|}{$(\mu \mathrm{g} / \mathrm{mg}$ protein $)$} \\
\hline \multirow[t]{2}{*}{ GSH } & $3.99 \pm 0.21$ & $2.14 \pm 0.16$ & $3.65 \pm 0.25$ & $3.85 \pm 0.31$ & $3.46 \pm 0.26$ & $3.06 \pm 0.25$ \\
\hline & & $\mathrm{a}^{*}$ & $b^{*}$ & $b^{*}$ & $a^{\#} b^{*} d^{@}$ & $a^{*} b^{*} c^{\#} d^{*} e^{@}$ \\
\hline \multirow[t]{2}{*}{ Vitamin $\mathrm{C}$} & $1.50 \pm 0.08$ & $1.23 \pm 0.08$ & $1.41 \pm 0.08$ & $1.56 \pm 0.07$ & $1.30 \pm 0.08$ & $1.41 \pm 0.07$ \\
\hline & & $\mathrm{a}^{*}$ & $b^{\#}$ & $\mathrm{~b}^{*} \mathrm{c} @$ & $\mathrm{a}^{\#} \mathrm{c}^{@} \mathrm{~d}^{*}$ & $b^{\#} d^{@}$ \\
\hline \multirow[t]{2}{*}{ Vitamin E } & $0.46 \pm 0.03$ & $0.29 \pm 0.01$ & $0.48 \pm 0.03$ & $0.43 \pm 0.04$ & $0.32 \pm 0.02$ & $0.38 \pm 0.02$ \\
\hline & & $\mathrm{a}^{*}$ & $\mathrm{~b}^{*}$ & $a^{*} b^{*} c^{\#}$ & $a^{*} c^{*} d^{*}$ & $a^{*} b^{*} c^{*} d^{\#} e^{*}$ \\
\hline
\end{tabular}

Values represent mean \pm SD for six rats. Treatment of groups: as in Table 1. Unit of enzyme activity: GPx, $\mu \mathrm{mol}$ of GSH; catalase, $\mu \mathrm{mol}$ of $\mathrm{H}_{2} \mathrm{O}_{2}$; SOD, amount of enzyme required to bring about $50 \%$ inhibition of autoxidation of pyrogallol; GR and G6PD, nmol of NADPH; GST, nmol of CDNB-GSH conjugate. Comparisons are made: as in Table 1. Symbols represent statistical significance: ${ }^{@} p<0.05 ;{ }^{\sharp} p<0.01 ;{ }^{*} p<0.001$.

Vol. 28, No. 1, 2000 
significant change towards normal in the treated animals.

\section{DISCUSSION}

Feeding the rats a diet deficient in pyridoxine for 21 days resulted in hyperoxaluria and crystal deposition, which deficiency is known to induce lipid peroxidation. The increased susceptibility of the kidney to peroxidative damage might be due to the high vascularity of the kidney.

Increased lipid peroxidation is associated with the depletion of the antioxidant status in the tissue. Replenishing the GSH levels is necessary for maintenance of the overall thiol status in the cell. The observed decrease in the GSH levels in the kidney of the hyperoxaluric rats might have been due to its increased conversion to GSSG. The consequence of this is the reduction in the regeneration of ascorbate from dehydroascorbate. Consequently, there is a hindrance to the regeneration of vitamin $\mathrm{E}$. This simultaneous decrease in the two vitamins leads to elevated lipid peroxidation [9]. The regeneration of GSH requires NADPH supplied by G6PD. A decrease in the G6PD activity seen in the pyridoxinedeficient rats explains the decreased GSH level. This also accounts for the decreased GR activity in these animals. Moreover, oxidative assault inhibits both GR and G6PD activities, as reported by Brin and Yonimoto [10].

Accumulation of hydrogen peroxide is injurious to cells. The increase in hydrogen peroxide levels in the cell can be supposed by the observed decrease in the GPx and catalase activities, the two enzymes responsible for the decomposition of hydrogen peroxide [11]. The reduction in the availability of the substrate of GPx might be the reason for the decrease in its activity. The results showed that the catalase activity was reduced by more than half in the pyridoxine-deficient animals. This might be a cumulative effect of the nephrotoxic effect of oxalate [12] and the decreased availability of NADPH, which is necessary for its regeneration from inactive forms [13]. On the other hand, Selvam and Ravichandran [14] also observed decreased SOD levels in pyridoxine-deficient rats. The combined effect of the three led to enhanced lipid peroxidation in the group II animals.

Lipid peroxidation levels were lowered remarkably, and also the antioxidant status of the kidney was restored, on treatment. Though the resultant change towards normal was similar with both lupeol and betulin treatment, overall lupeol was more efficacious; for a more significant change was observed in some parameters such as vitamins $\mathrm{E}$ and $\mathrm{C}$ and peroxidation in the presence of inducers such as ascorbate and ferrous sulphate. Earlier reports from our laboratory also showed that lupeol was a good cytoprotective agent against free radical-induced toxicity, in both urolithiasis and arthritis $[4,15]$. The present results further emphasize its efficacy against peroxidative damage to tissues.

This work forms part of the project funded by the Council for Scientific and Industrial Research, India, to Dr. P. Varalakshmi, which is gratefully acknowledged.

J. Clin. Biochem. Nutr. 


\section{REFERENCES}

1. Varalakshmi, P., and Richardson, K.E. (1982): The effects of vitamin $B_{6}$ deficiency on hepatectomy on the synthesis of oxalate from glycolate in the rat. Biochim. Biophys. Acta, 757, 1-7.

2. Ernster, L., and Nordenbrand, K. (1967): Oxidation and phosphorylation, in Methods in Enzymology, Vol. X, ed. by Ronald, W.E., Maynard, E.P., Academic Press, New York, pp. 574-580.

3. Bala Nehru, S., and Nagarajan, B. (1991): Protective effect of oleanolic acid and ursolic acid against lipid peroxidation. Biochem. Int., 24, 981-990.

4. Baskar, R., Malini, M.M., Varalakshmi, P., Balakrishna, K., and Bhima Rao, R. (1996): Effect of lupeol isolated from Crataeva nurvala stem bark against free radical-induced toxicity in experimental urolithiasis. Fitoterapia, LXVII, 121-125.

5. Chow, F.H.C., Dysart, M.I., Hamar, D.W., and Udhall, R.H. (1974): Control of oxalate urolithiasis by DL-alanine. Invest. Urol., 13, 113-116.

6. Sumathi, R., Jayanthi, S., Kalpanadevi, V., and Varalakshmi, P. (1993): Effect of DL $\alpha$-lipoic acid on tissue lipid peroxidation and antioxidant systems in normal and glycolate treated rats. Pharmacol. Res., 27, 309-317.

7. Omaye, S.T., Turnbull, J.D., and Sauberlich, H.E. (1979): Selected methods for the determination of ascorbic acid in animal cell, tissues and fluids. Methods Enzymol., 62, 1-11.

8. Quaife, M.C., and Dju, M.Y. (1948): Chemical estimation of vitamin E in tissue and $\alpha$-tocopherol content of normal tissues. J. Biol. Chem., 180, 263-272.

9. Selvam, R., and Ravichandran, V. (1991): Lipid peroxidation in liver of vitamin $B_{6}$ deficient rats. J. Nutr. Biochem., 2, 245-250.

10. Brin, M., and Yonimoto, R.H. (1958): Stimulation of glucose oxidative pathway in human erythrocytes by methylene blue. J. Biol. Chem., 230, 307-311.

11. Gaetani, G.F., Galiano, S., Canepa, L., Ferraris, A.M., and Kirkman, H.N. (1989): Catalase and glutathione peroxidase are equally active in detoxification of hydrogen peroxide in human erythrocytes. Blood, 73, 334-339.

12. Selvam, R., and Biji Kurien, T. (1987): Induction of lipid peroxidation by oxalate in experimental rat urolithiasis. J. Biosci., 12, 367-373.

13. Kirkman, H.N., and Gaetani, G.F. (1984): Catalase: A tetrameric enzyme with four tightly bound molecules of NADPH. Proc. Natl. Acad. Sci. U.S.A., 81, 4343-4347.

14. Selvam, R., and Ravichandran, V. (1993): Restoration of tissue antioxidants and prevention of renal stone deposition in vitamin $\mathrm{B}_{6}$ deficient rats fed with vitamin $\mathrm{E}$ or methionine. Indian J. Exp. Biol., 31, 882-887.

15. Geetha, T., Varalakshmi, P., and Marylatha, R. (1998): Effect of triterpenes from Crataeva nurvala stem bark on lipid peroxidation in adjuvant induced arthritis in rats. Pharm. Res., 37, 191-195. 